\title{
INFLUENCE OF ITALIAN RYEGRASS (Lolium multiflorum Lam.) AS INTERCROP WITH SPRING BARLEY (Hordeum vulgare L.) ON THE DIVERSITY OF WEED COMMUNITIES
}

\author{
Krzysztof Orzech, Maria Wanic \\ Department of Agricultural Systems, University of Warmia and Mazury in Olsztyn \\ ul. Pl. Łódzki 3, 10-718 Olsztyn, Poland \\ e-mail: krzysztof.orzech@uwm.edu.pl,maria.wanic@uwm.edu.pl
}

Received: 30.04.2013

\begin{abstract}
The paper presents results of 3 years of studies (20092011) on the influence of Italian ryegrass on the development of weed communities in spring barley (without chemical weeds control) cultivated after potato, spring wheat and spring barley. The reaction of spring barley to the choice of the forecrop was compared with identical plots with pure stand of that cereal where herbicides were applied for weeds control. Evaluation of infestation with weeds was conducted during barley tillering and before harvest. That evaluation considered the number and composition of weed species. During harvest, the dry mass of weeds was also considered. The results were used for determination of Shannon-Wiener diversity index and species homogeneity coefficient, Simpson's index of dominance as well as Sørensen similarity index.

Spring barley weeding was significantly higher in case of cultivating it in mixed stand with Italian ryegrass (without chemical control), than in pure stand (with control). In the plots with mixed crop, lower diversity and homogeneity of weeds' communities were recorded than in pure stand. Barley in mixed crop sown after spring barley, during both times of evaluation (spring and before harvest), increased the value of the index of dominance according to the number of species the most. As concerns the composition of species, number and biomass, the communities of pure stand and mixed crop with Italian ryegrass on the plot after potato were the most similar.
\end{abstract}

Key words: Lolium multiflorum, mixed crop, number and biomass of weeds, diversity of weeds, similarity of communities, indicators, Hordeum vulgare.

\section{INTRODUCTION}

High sensitivity of cereals to consecutive cultivation and in monoculture resulted in the necessity of searching for methods of limiting the negative con- sequences resulting from that. Mixed cropping, including crops intended for green fertiliser is one of the solutions [1]. Mixed crops increase the number of species in the crops rotation system and make a break in continual cultivation of cereals after the same cereals in the same field improving significantly the plot for the consecutive crops [2,3], as well as the entire rotation systems [4]. They supply significant volumes of surface biomass and harvest residues becoming a significant source of organic matter [5-7]. They limit soil erosion, intensity of diseases and weeding of crops [8-11]. During the recent years, numerous works on the roles of intercrops saturated with cereals and in particular, their influence on weeding of crops were published. The majority of them concern stubble field intercrops [12-14]. Less information is found on the regulatory function of added crops on the weeds and the results of studies presented so far are not clear [15-20].

Considering the above, the research hypothesis was formulated that assumed that introduction of Italian ryegrass in the plot of spring barley as mixed crop would be so effective in limiting the weeding that application of herbicides might prove redundant. The hypothesis was verified by means of the field experiment.

The aim of the work was to determine the influence of Italian ryegrass applied in mixed crop on the development of communities of weeds in spring barley cultivated after different forecrops.

\section{MATERIALS AND METHODS}

Strict static two-factor experiment was completed during the years 2009-2011 on the experimental fields of the Production-Experimental Enterprise in 
Bałcyny near Ostróda (5336’ N, 1951’ E), belonging to the University of Warmia and Mazury in Olsztyn. The experiment was established in the system of random blocks in 4 repetitions. Spring barley sowing method (pure stand with chemical protection and mixed crop with Italian ryegrass without protection) was the first while the forecrop (potato, spring wheat and spring barley) was the second factor. The experiment was established on the typical medium grey-brown podzolic soil formed from light clay. The soil contained from 8.9 to $10.4 \mathrm{~g} \times \mathrm{kg}^{-1}$ of organic carbon in the cultivated layer $(0-20 \mathrm{~cm})$. It was acid $\left(\mathrm{pH}_{\mathrm{KCl}} 5.5-5.7\right)$ and it was characterised by phosphorus content of 80 to $99 \mathrm{mg} \times \mathrm{kg}^{-1}$ (high to very high availability), potassium of 182 to $233 \mathrm{mg} \times \mathrm{kg}^{-1}$ (high to very high availability) and magnesia of 36 to $47 \mathrm{mg} \times \mathrm{kg}^{-1}$ (low availability).

The sowing standard for spring barley (Hordeum vulgare) 'Rastik' cultivar in pure stand and mixed crop was 500 germinating seedlings per $1 \mathrm{~m}^{2}$. On the mixed crop field, Italian ryegrass (Lolium multiflorum) 'Gaza' cultivar at $24 \mathrm{~kg} \times \mathrm{ha}^{-1}$ was sown simultaneously with the cereal.

Cultivation on all experimental plots was conducted by traditional (tillage) method. Mineral fertilisation was adjusted to the nutrients' availability in the soil. It was not diversified by the method of spring barley sowing or the forecrop and it was $\left(\mathrm{kg} \times \mathrm{ha}^{-1}\right)$ : $\mathrm{N}-60 ; \mathrm{P}-35$ and $\mathrm{K}-66$.

Pure stand of spring barley was protected against dicotyledonous weeds from the tillering stage $(\mathrm{BBCH}$ 23-29) until stem elongation stage $(\mathrm{BBCH} 30-32)$ by applying florasulum and 2,4-D acid at $0.51 \times \mathrm{ha}^{-1}$ (Mustang $306 \mathrm{SE}$ ). In case of barley cultivated with Italian ryegrass, no chemical protection was applied. Evaluation of the actual weeding was conducted yearly before applying the herbicides during the initial stage of barley tillering (BBCH 21-22) and before its harvest $(\mathrm{BBCH}$ 89-92). It covered the number as well as composition of weed species on the surface of $1 \mathrm{~m}^{2}$, and during the harvest also the air-dry mass of the weeds. The meas- urements were performed by applying the frame method in two repetitions in each plot. The results obtained were applied for computation of the Simpson's index of dominance [21] as well as Shannon-Wiener diversity index and species homogeneity coefficient $[22,23]$. The biological indicators were computed according to the formulas:

- Shannon-Wiener diversity index $\left(\mathrm{H}^{\prime}\right): \mathrm{H}^{\prime}=$ $-\Sigma\left(\mathrm{p}_{\mathrm{i}} \times \ln \mathrm{p}_{\mathrm{i}}\right)$,

- Shannon-Wiener species homogeneity coefficient (J'): J' $=\mathrm{H}^{\prime} \times(\ln S)^{-1}$,

- Simpson's index of dominance $(\lambda): \lambda=\Sigma p_{i}{ }^{2}$.

Weed communities were compared by applying the Sørensen similarity index [24] applying the formula $\mathrm{P}=2 \mathrm{c} \times 100(\mathrm{a}+\mathrm{b})^{-1}$.

The results obtained were processed statistically by means of the variance analysis method by applying the Duncan's test at the significance level of $p=$ 0.05 . The analysis of correlation between the number and biomass of weeds and the barley yield was also conducted. The names of weeds were assumed after Mirek et al. [25].

\section{RESULTS}

During the three-year experimental cycle significantly more weeds were found in the plot with the intercrop of Italian ryegrass during the tillering stage per unit of area (in average by $16.8 \%$ ) than in the pure stand (Table 1). The forecrop also had significant influence on the investigated characteristic. In the field after spring wheat, the weeding was higher (in average by $28.7 \%$ ) as compared to the field after potato or after spring barley. In pure stand, both cereal forecrops contributed to significant increase in the number of weeds (in average by $34.4 \%$ ) as compared to the plot after potato. On the other hand, significant increase in the number of weeds occurred in the plot after spring wheat (by 63.6\%) as compared to the consecutive cultivation of that cereal.

Table 1

Number of weeds at the spring barley tillering stage, units $\cdot \mathrm{m}^{-2}$ (average for 2009-2011)

\begin{tabular}{lcccc}
\hline \multirow{2}{*}{ Stand type } & \multicolumn{3}{c}{ Previous crop } & \multirow{2}{*}{ Average } \\
\cline { 2 - 4 } & potato & spring wheat & spring barley & \\
\hline Pure stand & $125 \mathrm{~b}$ & $169 \mathrm{a}$ & $167 \mathrm{a}$ & $154 \mathrm{a}$ \\
With the intercrop & $192 \mathrm{a}$ & $216 \mathrm{a}$ & $132 \mathrm{~b}$ & $180 \mathrm{~b}$ \\
Average & $150 \mathrm{a}$ & $193 \mathrm{~b}$ & $150 \mathrm{a}$ & $\mathrm{x}$ \\
\hline
\end{tabular}

$a, b-$ values marked with the same letter do not differ significantly at $p=0,05$

The sowing method did not differentiate the abundance of weed communities that consisted of 13 to 16 taxa significantly (Table 2). In case of both sowing methods Thlaspi arvense, Chenopodium album, Fallo- pia convolvulus and Veronica arvensis had the highest shares in the communities representing together $69.8 \%$ to $79 \%$ of all the weeds. 
Table 2

Number of weed species in the community during spring barley tillering stage, units $\times \mathrm{m}^{-2}$ (average for 2009-2011)

\begin{tabular}{|c|c|c|c|c|}
\hline \multirow{2}{*}{ Species } & \multicolumn{3}{|c|}{ Previous crop } & \multirow{2}{*}{ Average } \\
\hline & Potato & spring wheat & spring barley & \\
\hline \multicolumn{5}{|c|}{ barley without the intercrop } \\
\hline Thlaspi arvense & 29.6 & 54.0 & 41.0 & 41.5 \\
\hline Chenopodium album & 43.6 & 30.3 & 32.2 & 35.4 \\
\hline Fallopia convolvulus & 17.3 & 20.0 & 16.0 & 17.8 \\
\hline Veronica arvensis & 4.3 & 13.0 & 21.7 & 13.0 \\
\hline Stellaria media & 7.0 & 8.7 & 6.7 & 7.5 \\
\hline Polygonum aviculare & 3.2 & 5.2 & 7.0 & 5.1 \\
\hline Viola arvensis & 4.3 & 5.0 & - & 3.1 \\
\hline Other & 15.5 & 32.7 & 42.3 & 30.2 \\
\hline Number of species & 13 & 19 & 16 & $\mathrm{x}$ \\
\hline \multicolumn{5}{|c|}{ barley with the intercrop } \\
\hline Chenopodium album & 68.0 & 60.7 & 28.3 & 52.3 \\
\hline Thlaspi arvense & 40.3 & 56.7 & 53.0 & 50.0 \\
\hline Fallopia convolvulus & 26.0 & 29.3 & 6.7 & 20.7 \\
\hline Veronica arvensis & 14.0 & 21.7 & 22.0 & 19.2 \\
\hline Stellaria media & 6.3 & 14.3 & 9.3 & 10.0 \\
\hline Polygonum aviculare & 2.0 & 2.7 & 0.3 & 1.7 \\
\hline Polygonum lapatifolium & 7.3 & 2.7 & 1.7 & 3.9 \\
\hline Other & 27.7 & 27.8 & 10.3 & 21.9 \\
\hline Number of species & 18 & 15 & 13 & $\mathrm{x}$ \\
\hline
\end{tabular}

The mixed crop was more favourable to germination of Thlaspi arvense (by 20.5\%), Chenopodium album (by 47.7\%), Fallopia convolvulus (by 16.3\%), Veronica arvensis (by 47.7\%) and (except the field after potato) Stellaria media (by 64.4\%) than pure stand of spring barley. In this case, increased occurrence of Polygonum lapathifolium was also recorded. Cultivation of barley with the intercrop, compared to pure stand, after potato and spring, wheat increased the population of Chenopodium album (by 56.0 and $100.3 \%$ respectively), Fallopia convolvulus and Veronica arvensis (by 50.3 and $66.9 \%$ ). Cultivation after potato increased also the presence of Thlaspi arvense (by
$36.1 \%$ ) and cultivation after spring wheat increased also the presence of Stellaria media (by 64.4\%). Consecutive cultivation of barley in mixed crop supported germination of Thlaspi arvense and Stellaria media (by 29.3 and $38.8 \%$ ).

The numbers of weeds determined during the spring decreased at the end of vegetation by $55.8 \%$ on the pure stand plots and by $64.6 \%$ on the mixed crop plots (Table 3 ). Thus, the weeding of barley cultivated with ryegrass was significantly higher (by $70.6 \%$ ) than in the pure stand. On the other hand, no significant influence of the forecrop on the analysed characteristic was found in case either sowing method.

Table 3

Number of weeds before spring barley harvest, units $\cdot \mathrm{m}^{-2}$ (average for 2009-2011)

\begin{tabular}{lcccc} 
& \multicolumn{3}{c}{ Previous crop } & \multirow{2}{*}{ Average } \\
\cline { 2 - 3 } Stand type & potato & spring wheat & spring barley & \\
\hline Pure stand & $68 \mathrm{a}$ & $63 \mathrm{a}$ & $74 \mathrm{a}$ & $68 \mathrm{a}$ \\
With the intercrop & $117 \mathrm{a}$ & $120 \mathrm{a}$ & $110 \mathrm{a}$ & $116 \mathrm{~b}$ \\
Average & $93 \mathrm{a}$ & $92 \mathrm{a}$ & $92 \mathrm{a}$ & $\mathrm{x}$ \\
\hline
\end{tabular}

$a, b$ - values marked with the same letter do not differ significantly at $p=0,05$ 
Table 4

Number of weeds species in the community before spring barley harvest, units $\times \mathrm{m}^{-2}$ (average for 2009-2011)

\begin{tabular}{|c|c|c|c|c|}
\hline \multirow{2}{*}{ Species } & \multicolumn{3}{|c|}{ Previous crop } & \multirow{2}{*}{ Average } \\
\hline & potato & spring wheat & spring barley & \\
\hline \multicolumn{5}{|c|}{ barley without the intercrop } \\
\hline Galinsoga parviflora & 19.0 & 15.2 & 16.7 & 17.0 \\
\hline Chenopodium album & 21.5 & 6.2 & 8.3 & 12.0 \\
\hline Thlaspi arvense & 10.5 & 2.7 & 11.7 & 8.3 \\
\hline Fallopia convolvulus & 1.0 & 7.5 & 6.0 & 4.8 \\
\hline Veronica arvensis & 4.7 & 5.9 & 3.3 & 4.6 \\
\hline Polygonum aviculare & 2.7 & 1.0 & 5.8 & 3.2 \\
\hline Other & 8.8 & 24.5 & 21.7 & 18.3 \\
\hline Number of species & 15 & 21 & 16 & $\mathrm{x}$ \\
\hline \multicolumn{5}{|c|}{ barley with the intercrop } \\
\hline Chenopodium album & 43.0 & 36.7 & 43.8 & 41.2 \\
\hline Thlaspi arvense & 26.0 & 29.7 & 26.7 & 27.5 \\
\hline Fallopia convolvulus & 21.3 & 8.7 & 10.3 & 13.4 \\
\hline Galinsoga parviflora & 7.7 & 13.0 & 6.3 & 9.0 \\
\hline Stellaria media & 3.7 & 4.0 & 4.7 & 4.1 \\
\hline Agropyron repens & 1.0 & 1.0 & 4.3 & 2.1 \\
\hline Polygonum aviculare & 1.0 & 0.3 & 2.0 & 1.1 \\
\hline Other & 13.3 & 26.3 & 12.2 & 17.3 \\
\hline Number of species & 17 & 21 & 16 & $\mathrm{x}$ \\
\hline
\end{tabular}

In case of barley cultivated in mixed crop with Italian ryegrass Chenopodium album, Thlaspi arvense, Fallopia convolvulus and Galinsoga parviflora had the highest share in the community; their combined share was from 73.4 to $83.8 \%$ of all the weeds (Table 4). In case of that object, the forecrops did not differentiate the numbers of Chenopodium album and Thlaspi arvense populations significantly. In the plot after potato, more numerous presence of Fallopia convolvulus was recorded. Following spring wheat, Galinsoga parviflora and following spring barley Agropyron repens were more numerous. Compared to the pure stand, the intercrop increased the numbers of Chenopodium album (2.0-5.9 times), Thlaspi arvense (2.3-11 times), Fallopia convolvulus (1.7-21.3 times), while it decreased the numbers of Galinsoga parviflora (by 14.5-62.3\%) and Polygonum aviculare and Stellaria media (which at the plot with pure stand was present in marginal numbers). The largest increase in Chenopodium album and Thlaspi arvense was determined in the field after spring wheat and of Fallopia convolvulus in the field after potato.

Compared to the pure stand cultivation, mixed cultivation of barley with the intercrop influences also the significant increase (exceeding 2-times) of the dry mass of weeds (Table 5). As concerns the average values for the sowing method, no significant influence of the forecrop on the analysed parameter was determined. The only observation made was that weeds showed clear trend of developing larger biomass when barley was cultivated after spring wheat or spring barley.

Table 5

Air-dry mass of weeds in the spring barley stand, $\mathrm{g} \times \mathrm{m}^{-2}$ (average for 2009-2011)

\begin{tabular}{lcccc}
\hline & \multicolumn{3}{c}{ Previous crop } & \multirow{2}{*}{ Average } \\
\cline { 2 - 4 } Stand type & potato & spring wheat & spring barley & \\
\hline Pure stand & $23.2 \mathrm{a}$ & $26.1 \mathrm{a}$ & $25.3 \mathrm{a}$ & $24.9 \mathrm{a}$ \\
With the intercrop & $36.5 \mathrm{a}$ & $62.9 \mathrm{ab}$ & $67.5 \mathrm{~b}$ & $55.6 \mathrm{~b}$ \\
Average & $29.8 \mathrm{a}$ & $44.6 \mathrm{a}$ & $46.4 \mathrm{a}$ & $\mathrm{x}$ \\
\hline
\end{tabular}

$a, b$ - values marked with the same letter do not differ significantly at $p=0,05$ 
In pure crop, no significant influence of forecrop on abundance of weeds was found. On the other hand, consecutive cultivation of spring barley increased the dry mass of weeds significantly (by $84.9 \%$ ) on the plot after potato. Larger (but not confirmed statistically) biomass compared to the plot after potato was also recorded on the plot after spring wheat. In both sowing methods, Chenopodium album and Fallopia convolvulus had the largest share in the community. In the pure stand, the share of Polygonum aviculare was also among the highest (Table 6). Particularly favourable conditions for development of Chenopodium album occurred in the plots with Italian ryegrass intercrop where the mass of the population of that weed averaged $38.1 \%$ of the weeds on the plot. The intercrop also favoured vegetation of Fallopia convolvulus (except the field after potato) and Galinsoga parviflora. The biomass of those three species was higher than in the pure stand by $4.8,2.6$ and 2.2 times respectively. On that object, the largest increase in Chenopodium album biomass occurred in the field with consecutive cultivation of barley (by 7.2 times as compared to the pure stand) while Galinsoga parviflora increased the most after spring wheat (2.8 times). Larger mass of Stellaria media, Agropyron repens and Cirsium arvense was also recorded while in the pure stand their share in the biomass was small. Cereal forecrops contributed to the increase in dry mass of Fallopia convolvulus in case of both pure and mixed stand while in pure stand also to the increase in dry mass of Polygonum aviculare. On the other hand, the plot after potato favoured vegetation of Thlaspi arvense. Cultivation of spring barley with Italian ryegrass after spring barley contributed to significant increase in the biomass of Chenopodium album (2.3 times as compared to the field after potato).

Table 6

Number of species in the total mass of weeds before spring barley harvest, $\mathrm{g} \times \mathrm{m}^{-2}$ (average for 2009-2011)

\begin{tabular}{|c|c|c|c|c|}
\hline \multirow{2}{*}{ Species } & \multicolumn{3}{|c|}{ Previous crop } & \multirow{2}{*}{ Average } \\
\hline & potato & spring wheat & spring barley & \\
\hline \multicolumn{5}{|c|}{ barley without the intercrop } \\
\hline Chenopodium album & 4.5 & 3.9 & 4.8 & 4.4 \\
\hline Fallopia convolvulus & 1.5 & 3.0 & 3.8 & 2.8 \\
\hline Polygonum aviculare & 0.5 & 3.5 & 4.5 & 2.8 \\
\hline Galinsoga parviflora & 2.3 & 2.5 & 2.1 & 2.3 \\
\hline Thlaspi arvense & 4.0 & 0.2 & 2.2 & 2.1 \\
\hline Veronica arvensis & 0.2 & 2.9 & 1.6 & 1.6 \\
\hline Echinochloa crus-galli & 2.5 & 1.2 & 0.8 & 1.5 \\
\hline Other & 7.7 & 8.9 & 5.5 & 7.4 \\
\hline \multicolumn{5}{|c|}{ barley with the intercrop } \\
\hline Chenopodium album & 14.8 & 14.2 & 34.6 & 21.2 \\
\hline Fallopia convolvulus & 1.4 & 9.5 & 10.6 & 7.2 \\
\hline Galinsoga parviflora & 3.6 & 6.9 & 4.5 & 5.0 \\
\hline Stellaria media & - & 4.5 & 4.4 & 3.0 \\
\hline Agropyron repens & 0.1 & 6.2 & - & 3.1 \\
\hline Cirsium arvense & 5.1 & 4.2 & - & 3.1 \\
\hline Thlaspi arvense & 4.6 & 3.2 & - & 2.6 \\
\hline Other & 6.9 & 14.2 & 13.4 & 11.5 \\
\hline
\end{tabular}

The computed indicators of biodiversity and homogeneity of weed communities assumed similar values for both periods of evaluation (spring and before harvest) (Table 7). Cultivation of spring barley in pure stand had significantly more favourable influence on the diversity and even share of individuals within the communities. It was more pronounced in the spring than at the end of vegetation. In case of both sowing methods, cultivation of barley after wheat increased the diversity of communities (except the biomass in pure stand where that indi- cator showed no significant changes under the influence of forecrop). In case of pure barley stand, the characteristic studied was also influenced positively by consecutive cultivation of barley. In the spring, the diversity smaller than in case of both sowing methods was recorded in the plot after potato and for the mixed crop additionally after spring barley while during harvest after the same forecrops but in case of barley cultivation with the intercrop. During both the spring and at the end of vegetation, the community of the field with consecutive cultivation 
of barley in pure stand was characterised by significantly more homogeneous populations of weeds. In the same plot but with the intercrop of Italian ryegrass larger differences were recorded in the size of individual populations (with the exception of evaluation of the number during harvest when no significant differences between the plots evaluated were determined).

During the tillering stage and before the barley harvest from plots with intercrop significantly larger domination of weeds, average for the forecrop, was recorded as compared to the pure stand of barley. That indicator assumed the highest value in the barley stand with the intercrop cultivated after spring barley. The plots with cultivation of barley after potato were characterised by equally high domination in numbers. Fields of pure stand after spring wheat showed the lowest level of domination by one or a few weed species.

Table 7

Biological indicators for communities of weeds in the stand of spring barley

\begin{tabular}{|c|c|c|c|c|c|c|c|c|}
\hline \multirow{3}{*}{ Indicators $^{*}$} & \multicolumn{4}{|c|}{ Barley without the intercrop } & \multicolumn{4}{|c|}{ Barley with the intercrop } \\
\hline & \multicolumn{8}{|c|}{ previous crop } \\
\hline & potato & spring wheat & spring barley & average & potato & spring wheat & spring barley & average \\
\hline \multicolumn{9}{|c|}{ barley tillering stage; according to number of species } \\
\hline $\mathrm{H}$, & $1.928 \mathrm{c}$ & $2.259 \mathrm{a}$ & $2.320 \mathrm{a}$ & $2.169 \mathrm{a}$ & $1.966 b$ & $1.984 \mathrm{ab}$ & $1.733 c$ & $1.894 \mathrm{~b}$ \\
\hline $\mathrm{J}$ & $0.752 b$ & $0.767 \mathrm{~b}$ & $0.837 \mathrm{a}$ & $0.785 \mathrm{a}$ & $0.680 \mathrm{~b}$ & $0.733 \mathrm{ab}$ & $0.656 b c$ & $0.690 \mathrm{~b}$ \\
\hline$\lambda$ & $0.210 \mathrm{a}$ & $0.164 b$ & $0.137 \mathrm{c}$ & $0.170 \mathrm{~b}$ & $0.196 \mathrm{ab}$ & $0.186 b$ & $0.242 \mathrm{a}$ & $0.208 \mathrm{a}$ \\
\hline \multicolumn{9}{|c|}{ before harvest barley; according to number of species } \\
\hline $\mathrm{H}$, & $1.906 \mathrm{a}$ & $2.538 \mathrm{a}$ & $2.358 \mathrm{a}$ & $2.267 \mathrm{a}$ & $1.848 \mathrm{c}$ & $2.127 \mathrm{a}$ & $1.884 \mathrm{c}$ & $1.953 b$ \\
\hline $\mathrm{J}$ & $0.704 b$ & $0.833 \mathrm{a}$ & $0.879 \mathrm{a}$ & $0.805 \mathrm{a}$ & $0.652 \mathrm{c}$ & $0.699 \mathrm{c}$ & $0.679 \mathrm{c}$ & $0.677 \mathrm{~b}$ \\
\hline$\lambda$ & $0.212 \mathrm{a}$ & $0.109 \mathrm{c}$ & $0.176 b$ & $0.166 b$ & $0.225 \mathrm{a}$ & $0.185 b$ & $0.235 \mathrm{a}$ & $0.215 \mathrm{a}$ \\
\hline \multicolumn{9}{|c|}{ before harvest barley; according to biomass } \\
\hline $\mathrm{H}$, & $2.289 \mathrm{a}$ & $2.211 \mathrm{a}$ & $2.318 \mathrm{a}$ & $2.273 \mathrm{a}$ & $1.965 b$ & $2.373 \mathrm{a}$ & $1.603 \mathrm{c}$ & $1.980 \mathrm{~b}$ \\
\hline $\mathrm{J}$ & $0.892 \mathrm{ab}$ & $0.738 b$ & $0.878 \mathrm{a}$ & $0.836 \mathrm{a}$ & $0.709 b$ & $0.779 \mathrm{~b}$ & $0.592 \mathrm{c}$ & $0.693 b$ \\
\hline$\lambda$ & $0.129 \mathrm{ab}$ & $0.109 b$ & $0.136 \mathrm{a}$ & $0.125 b$ & $0.123 b$ & $0.121 \mathrm{~b}$ & $0.308 \mathrm{a}$ & $0.184 a$ \\
\hline
\end{tabular}

* indicators: H'- Shannon-Wiener diversity index; J'- Shannon-Wiener evenness index; $\lambda$ - Simpson's domination index $\mathrm{a}, \mathrm{b}, \mathrm{c}-$ values marked with the same letter do not differ significantly at $\mathrm{p}=0,05$

Table 8

Species homogeneity coefficient for weed communities (\%) in spring barley cultivated in pure stand and with Italian ryegrass intercrop after different forecrops

\begin{tabular}{|c|c|c|c|c|c|}
\hline \multirow{3}{*}{$\begin{array}{l}\text { Comparison of weed } \\
\text { communities after } \\
\text { previous crops }\end{array}$} & \multicolumn{5}{|c|}{ Similarity according to } \\
\hline & $\begin{array}{c}\text { composition of } \\
\text { species }\end{array}$ & $\begin{array}{c}\text { number of } \\
\text { species }\end{array}$ & $\begin{array}{c}\text { composition of } \\
\text { species }\end{array}$ & $\begin{array}{c}\text { number of } \\
\text { species }\end{array}$ & dry mass \\
\hline & \multicolumn{2}{|c|}{ tillering stage } & \multicolumn{3}{|c|}{ before harvest } \\
\hline \multicolumn{6}{|c|}{ barley without the intercrop } \\
\hline Potato - Spring wheat & 75.0 & 72.9 & 72.2 & 56.6 & 56.0 \\
\hline Potato - Spring barley & 62.1 & 68.3 & 80.0 & 69.6 & 59.6 \\
\hline Spring wheat - Spring barley & 85.7 & 78.9 & 70.3 & 72.9 & 73.3 \\
\hline \multicolumn{6}{|c|}{ barley with the intercrop } \\
\hline Potato - Spring wheat & 78.8 & 78.9 & 78.9 & 75.5 & 61.5 \\
\hline Potato - Spring barley & 77.4 & 63.7 & 84.8 & 86.6 & 48.8 \\
\hline Spring wheat - Spring barley & 71.4 & 71.2 & 70.3 & 78.4 & 58.2 \\
\hline \multicolumn{6}{|c|}{ barley without the intercrop - Barley with the intercrop } \\
\hline Potato & 83.9 & 73.3 & 81.3 & 57.8 & 47.5 \\
\hline Spring wheat & 76.5 & 74.9 & 71.4 & 45.7 & 36.8 \\
\hline Spring barley & 62.1 & 82.5 & 77.4 & 48.0 & 37.7 \\
\hline
\end{tabular}


Evaluation of similarity of the analysed phytocenoses showed that during the tillering stage the individual pairs of communities were diversified at both objects (pure and mixed stand) (Table 8). As concerns the pure stands, the communities of the fields of spring wheat and spring barley were the most similar. The fields of potato and spring barley were the most similar in the composition of species during the harvest. The lowest similarity, on the other hand, was determined in the pair of potato-spring wheat at the end of vegetation of the analysed cereal. The object with the intercrop of Italian ryegrass, significant similarity was determined between the fields of potato-spring wheat and during the harvest between potato-spring barley. That last pair, however, was characterised by a big difference in the biomass of weeds. The comparison of spring barley sowing method shows that as concerns composition of species during both evaluation periods the fields after potato were the most similar. As concerns the number, the fields after spring barley were the most similar in the spring. At the end of vegetation, the communities in the plots after cereal forecrops differed the least.

The yield of spring barley grain from the field with the intercrop of Italian ryegrass (without chemical protection) was lower by $10.9 \%$ than the yield from the pure stand (with protection) (tab. 9). The intercrop proved the factor mitigating the influence of forecrops on the yield of that cereal as opposed to the pure stand where a significant yield decrease was recorded in the plot with consecutive cultivation of spring barley. Correlation analysis showed significant negative correlation between the number and mass of weeds during harvest and the yield of barley $(r=-0543$ and - 0, 611 respectively).

Table 9

Yields of spring barley grain $\left(\mathrm{t} \times \mathrm{ha}^{-1}\right)$ (average for the years 2009-2011)

\begin{tabular}{lcccc}
\hline \multirow{2}{*}{ Stand type } & \multicolumn{3}{c}{ Previous crop } & \multirow{2}{*}{ Average } \\
\cline { 2 - 4 } & potato & spring wheat & spring barley & $5.23 \mathrm{a}$ \\
\hline Pure stand & $5.45 \mathrm{a}$ & $5.30 \mathrm{a}$ & $4.93 \mathrm{~b}$ & $4.66 \mathrm{~b}$ \\
With the Italian ryegrass intercrop & $4.70 \mathrm{a}$ & $4.61 \mathrm{a}$ & $4.66 \mathrm{a}$ & $\mathrm{x}$ \\
Average & $5.08 \mathrm{a}$ & $4.96 \mathrm{a}$ & $4.80 \mathrm{~b}$ & \\
\hline
\end{tabular}

$a, b$ - values marked with the same letter do not differ significantly at $p=0,05$

\section{DISCUSSION}

Cultivation of spring barley with Italian ryegrass as the intercrop contributed to significant increase of weeding. In case of that facility, cultivation of barley after spring wheat increased the number of weeds significantly as compared to consecutive cultivation of the analysed cereal. W a n i c et al. [26] recorded different results. In the studies by the quoted authors, Italian ryegrass limited the number of weeds significantly - by $30 \%$, in case of consecutive cultivation of barley and cultivation of barley after potato (as compared to pure stand by 30 and $14 \%$ respectively). Similarly, P f a z a and C e g la rek [18] determined significant decrease of spring barley weeding under the influence of Italian ryegrass and its mix with white clover as the intercrops. On the other hand, Thorsted et al. [19] showed that the intercrop of white clover in oats, as compared to the pure stand of that cereal, did not limit weeding. Tendziagolska [27] documented significant decrease in the number of weeds in oats under the influence of the intercrop of white clover. J a strzę bs ka [17] claims that intercrops may also influence weeding of the following crops. The results different from our results are the consequence of the fact that in the analysed experi- ment, in case of pure stand of barley, herbicides were applied to control weeding. Thus, the intercrop may prove a good method for controlling the weeding but its weeding controlling capacity does not match that of the chemical herbicides.

During own studies, no significant influence of the intercrop on the number of species present in the field was found, which shows a contradiction with the results presented by $\mathrm{W}$ a $\mathrm{n}$ i c et al. [26], who recorded a definitely richer set of weed species in the pure crop than in the mixed stand of barley and the forecrop. In case of both sowing methods Chenopodium album, Thlaspi arvense and Fallopia convolvulus dominated. Also Kostrzewska et al. [28] determined that Chenopodium album was the dominating weed in the stand of spring barley. Similar findings are found in the work by $\mathrm{G}$ a w ę $\mathrm{d}$ a [12].

In the experiment conducted, cultivation of barley with the intercrop influenced increase of the dry mass of weeds significantly as compared to the pure stand. Consecutive cultivation of spring barley with Italian ryegrass after spring barley increased the dry mass of weeds significantly as compared to the situation in case of potato as the forecrop. Chenopodium album, Fallopia convolvulus and Galinsoga parviflora had the largest share in the total mass of weeds in the 
plots with the intercrop. Slightly different results were recorded by W a n i c et al. [20] and K o s tr ze w s ka et al. [28] who showed that the Italian ryegrass as intercrop in spring barley limited growth and development of weeds significantly. Similarly, $\mathrm{P} \nmid \mathrm{az}$ a and C e glarek [18] claimed that ryegrass in barley reduces the number and dry mass of weeds. In the studies by $\mathrm{W}$ a $\mathrm{nic}$ et al. [26], ryegrass limited the biomass of weeds in plots after potato and spring barley more than clover, reducing the dry mass of Chenopodium album and Fallopia convolvulus.

In own studies, the diversity of weed communities during the barley tillering stage and at the end of vegetation showed similarity. On the other hand, K o strzewska et al. [28] showed higher diversity and homogeneity indicators before spring barley harvest than during the cereal tillering stage. Also $\mathrm{S}$ t u p nicka-Rodzynkiewicz et al. [29] recorded larger diversity of species during the full vegetation of the cereals. The computed indicators of diversity and homogeneity were diversified by both the sowing method and the sequence of crops within the rotation system. Lower values of the analysed indicators were recorded in the objects with ryegrass. This was more pronounced before harvest of the analysed cereal than during the tillering stage. In own studies, the highest value of the dominance indicator according to the number of species (objects with the intercrop) was recorded in case of consecutive cultivation of barley. The largest similarity between pure stand and mixed stand was found in the field after potato. Kos tr ze w s k a et al. [28] recorded different results showing minor differences in the diversity of weed species in spring barley under the influence of Italian ryegrass as the intercrop and of the forecrops.

\section{CONCLUSIONS}

1. Weeding of spring barley with Italian ryegrass as intercrop (without protection) was higher than that of the pure stand (without protection). The intercrop contributed to more numerous presence of weeds at the plots after spring wheat in the spring and to increasing the dry mass of weeds in the field with consecutive cultivation of spring barley at the end of vegetation.

2. The sowing method did not diversify the abundance of species in the communities of weeds.

3. In the objects with the intercrop the communities were dominated in numbers by Chenopodium album, Fallopia convolvulus and Thlaspi arvense, while as concerns the biomass by Chenopodium album, Fallopia convolvulus and Galinsoga parviflora.

4. Communities of weeds in the stand of barley with intercrop were characterised by lower diversity and higher domination that was the case in pure stand. In case of both sowing methods, the plots after spring wheat were the most diversified while the plots after spring barley were dominated the most by one or a few species of weeds.

\section{Acknowledgements}

The present research it realize within the confines of statutory research of Departament of Agricultuaral Systems, University of Warmia and Mazury in Olsztyn

\section{Authors' contributions}

The following declarations about authors' contributions to the research have been made: concept of the study: $\mathrm{KO}, \mathrm{MW}$; field research and collecting data: $\mathrm{KO}, \mathrm{MW}$; data interpretation: $\mathrm{KO}$, MW; writing of the manuscript, table: KO, MW.

\section{REFERENCES}

1. A ndrzejewska J. Międzyplony w zmianowaniach zbożowych. Post Nauk Roln. 1999; 1(277): 19-31.

2. Cherr CM, Scholberg JMS, McSorley R. Green manure approaches to crop production. Agron J. 2006; 98(2): 302. http://dx.doi.org/10.2134/agronj2005.0035

3. Müller T, Thorup-Kristensen K, Magid J, Jensen LS, Hansen S. Catch crops affect nitrogen dynamics in organic farming systems without livestock husbandry - simulations with the DAISY model. Ecol Model. 2006; 191(3-4): 538-544. http://dx.doi.org/10.1016/j. ecolmodel.2005.05.026

4. Jaskulska J, Gałęzewski L. Aktualna rola międzyplonów w produkcji roślinnej i środowisku. Fragm Agron. 2009; 26(3): 48-57.

5. B orresen T. Ryegrass and white clover undersown in small grains at three nitrogen levels and four tillage treatments: after-effect on grain yields and soil structure. In: Lindén B, editor. The use of catch or cover crops to reduce leaching and erosion. Knivsta, Swedwn: Nordiska Jordbruksforskares Förening; 1995. p. 25-32.

6. Svensson KS, Lewan E, Clarholm M. Effects of a ryegrass catch crop on microbial biomass and mineral nitrogen in an arable soil during winter. Swed J Agric Res. 1994; 24(1): 31-38.

7. Thomsen IK, Christensen BT. Yields of wheat and soil carbon and nitrogen contents following long-term incorporation of barley straw and ryegrass catch crops. Soil Use Manag. 2006; 20(4): 432-438. http://dx.doi.org/ 10.1111/j.1475-2743.2004.tb00393.x

8. Acharya BD, Khattri GB, Chettri MK, Srivastava SC. Effect of Brassica campestris var. toria as a catch crop on Orobanche aegyptiaca seed bank. Crop Prot. 2002; 21(7): 533-537. http://dx.doi.org/10.1016/ S0261-2194(01)00137-5 
9. Akemo MC, Regnier EE, Bennett MA. Weed suppression in spring-sown rye (Secale cereale)-pea (Pisum sativum) cover crop mixes. Weed Technol. 2000; 14(3): 545-549. http://dx.doi.org/10.1614/0890-037X(2000)014[0 545:WSISSR]2.0.CO;2

10. Teasdale J, Beste E, Potts W. Response of weeds tillage and crop residue. Weed Sci. 1991; 39: 195-199.

11. Parylak D, Kita W. Zabiegi regeneracyjne a porażenie pszenżyta ozimego w monokulturze przez choroby podstawy źdźbła. Prog Plant Prot. 40: 627-630.

12. Gawęda D. Wpływ międzyplonów ścierniskowych na zachwaszczenie jęczmienia jarego uprawianego w monokulturze. Ann UMCS Agric. 2009; 64(3): 21-28.

13. Kwiatkowski C. Wpływ międzyplonu na plonowanie i zachwaszczenie jęczmienia jarego uprawianego w monokulturze. Ann UMCS Sect E. 2004; 59(2): 809-815.

14. Marshall EJP, Brown VK, Boatman ND, Lutman PJW, Squire GR, Ward LK. The role of weeds in supporting biological diversity within crop fields. Weed Res. 2003; 43(2): 77-89. http://dx.doi.org/10. 1046/j.1365-3180.2003.00326.x

15. Hartl W. Influence of undersown clovers on weeds and on the yield of winter wheat in organic farming. Agric Ecosyst Env. 1989; 27(1-4): 389-396. http://dx.doi.org/ 10.1016/0167-8809(89)90099-6

16. Hiltbrunner J, Jeanneret P, Liedgens M, St a m p P, Streit B. Response of weed communities to legume living mulches in winter wheat. J Agron Crop Sci. 2007; 193(2): 93-102. http://dx.doi.org/10.1111/j.1439-03 7X.2007.00250.X

17. Jastrzębska M. Mieszanki odmianowe pszenicy ozimej i jęczmienia jarego w płodozmianach zbożowych. Olsztyn: Wydawnictwo Uniwersytetu Warmińsko-Mazurskiego; 2009. (Rozprawy i Monografie - Uniwersytet Warmińsko-Mazurski w Olsztynie; vol 151).

18. Pła za A, Ceglarek F. Wpływ wsiewek na zachwaszczenie jęczmienia jarego. Prog Plant Prot. 2008; 48: 14621465.

19. Thorsted MD, Olesen JE, Koefoed N. Effects of white clover cultivars on biomass and yield in oat/clover intercrops. J Agric Sci. 2002;138(3):261-267. http://dx.doi. org/10.1017/S0021859602002010

20. Wanic M, Kostrzewska MK, Jastrzębska M, Brzezin GM. Rola wsiewek międzyplonowych w regulacji zachwaszczenia jęczmienia jarego w płodozmianach zbożowych. Fragm Agron. 2004; 1(18): 85-102.

21. Simps on EH. Measurement of diversity. Nature. 1949; 163(4148): 688-688. http://dx.doi.org/10.1038/163688a0

22. Shannon CE. A mathematical theory of communications. Bell Syst Tech J. 1948; 27: 379-424.

23. Wiener N. Cybernetics or control and communications in the animals and the machine. Cambridge, MA: The MIT Press; 1948.

24. Sørensen T. A method of establishing groups of equal amplitude in plant society based on similarity of species content. K Dan Vidensk Selesk. 1948; 5: 1-34.
25. Mirek Z, Piękoś-Mirkowa H, Zając A, Zają c M. Vascular plant sof Poland - a checklist. Cracow: W. Szafer Institute of Botany, Polish Academy of Sciences; 1995. (Polish botanical studies - guidebook series; vol 15).

26. Wanic M, Jastrzębska M, Nowicki J. Wsiewki międzyplonowe a zachwaszczenie jęczmienia jarego uprawianego w różnych stanowiskach. Fragm Agron. 2005; 2: 238-248.

27. Tendziagolska E. Zmiany wybranych właściwości fizycznych gleby w uprawie owsa nagiego w systemie ekologicznym. Probl Inż Rol. 2010; 2: 31-39.

28. Kostrzewska MK, Wanic M, Jastrzębska M, Now i cki J. Wpływ życicy wielokwiatowej jako wsiewki międzyplonowej na różnorodność zbiorowisk chwastów w jęczmieniu jarym. Fragm Agron. 2011; 28(3): 42-52.

29. Stupnicka-Rodzynkiewicz E, Stepnik K, A L. Wpływ zmianowania, sposobu uprawy roli i herbicydów na bioróżnorodność zbiorowisk chwastów. Acta Sci Pol Agric. 2004; 3(2): 235-245.

\section{Wpływ życicy wielokwiatowej (Lolium multiflorum Lam.) jako wsiewki międzyplonowej na różnorodność zbiorowisk chwastów w jęczmieniu jarym (Hordeum vulgare $\mathrm{L}$.)}

\section{Streszczenie}

W pracy przedstawiono 3-letnie (2009-2011) wyniki badań nad wpływem życicy wielokwiatowej na kształtowanie się zbiorowisk chwastów w jęczmieniu jarym (nie odchwaszczanym chemicznie) uprawianym w następstwie po ziemniaku, pszenicy jarej i po sobie. Reakcję jęczmienia na dobór przedplonów porównywano na tle analogicznych stanowisk z siewem czystym tego zboża, w którego łanie do regulacji zachwaszczenia zastosowano herbicydy. Ocenę zachwaszczenia przeprowadzono $\mathrm{w}$ fazie krzewienia jęczmienia i przed jego zbiorem. Uwzględniała ona liczebność i skład gatunkowy chwastów, a podczas zbioru również ich suchą masę. Wyniki te posłużyły do obliczeń wskaźników różnorodności i równomierności gatunkowej Shannona-Wienera, dominacji Simpsona i współczynnika podobieństwa Sørensena.

Zachwaszczenie jęczmienia jarego było istotnie większe w warunkach jego uprawy z wsiewką życicy wielokwiatowej (bez ochrony chemicznej), niż w siewie czystym (z ochroną). Na obiektach z wsiewką odnotowano mniejszą różnorodność i równomierność zbiorowisk chwastów niż w siewie czystym. Jęczmień $\mathrm{z}$ wsiewką $\mathrm{w}$ obu terminach oceny (wiosną i przed zbiorem) w najwyższym stopniu podwyższył wartość wskaźnika dominacji według liczebności gatunków 
w stanowisku po sobie. Pod względem składu gatun- siebie były zbiorowiska siewu czystego i z wsiewką kowego, liczebności i biomasy najbardziej podobne do życicy wielokwiatowej na polu po ziemniaku.

Handling Editor: Elżbieta Weryszko-Chmielewska

This is an Open Access digital version of the article distributed under the terms of the Creative Commons Attribution 3.0 License (creativecommons.org/licenses/by/3.0/), which permits redistribution, commercial and non-commercial, provided that the article is properly cited.

CThe Author(s) 2014 Published by Polish Botanical Society 